\title{
ANALISIS POTENSI EKONOMI SEKTORAL PADA EMPAT KABUPATEN DI PULAU MADURA
}

\author{
Oleh: \\ Azmi Faiz Nur \\ Alumni Fakultas Ekonomi Universitas Muhammadiyah Malang \\ E-mail/No. Hp: azmi_FN@gmail.com/- \\ Ida Nuraini \\ Fakultas Ekonomi Universitas Muhammadiyah Malang \\ E-mail/No. Hp: nurainiida@yahoo.com/08125271207
}

\begin{abstract}
The purpose of this research is to determine the pattern of the economy, the advanced sector/subsector on each district, and determining the growth center on the Madura Island. The analysis tools that are used in this research are Typology Klassen, Location Quotient (LQ), and analysis of gravity. The research concluded there are four (4) patterns of economic growth on four districts in the Madura Island. An area that "fast advance and grow" is Bangkalan, "the advanced but depressed" is Sumenep, the "growing fast" is Pamekasan, and the "relatively low" is district Sampang.
\end{abstract}

Keywords: Patterns of economic growth, competitive sector and growth pole.

\begin{abstract}
Abstrak
Tujuan penelitian ini adalah untuk mengetahui pola perekonomian, sektor/subsektor unggulan dan bukan unggulan pada masing - masing kabupaten, dan menentukan pusat pertumbuhan di pulau Madura. Alat analisis yang digunakan dalam penelitian ini adalah Tipologi Klassen, Location Quotient (LQ), dan analisis Gravitasi. Hasil penelitian menyimpulkan berdasarkan Tipologi Klassen diketahui ada empat pola pertumbuhan ekonomi pada masing - masing kabupaten di pulau Madura. Daerah yang "cepat maju dan tumbuh" adalah Kabupaten Bangkalan, daerah "maju tapi tertekan" adalah Kabupaten Sumenep, daerah "berkembang cepat" adalah Kabupaten Pamekasan, dan daerah "relatif tertinggal” adalah Kabupaten Sampang.
\end{abstract}

Kata Kunci: Pola pertumbuhan ekonomi, sektor unggulan dan pusat pertumbuhan

\section{PENDAHULUAN}

Fenomena perekonomian di Indonesia belakangan ini begitu cepat berubah seiring dengan berjalannya waktu. Berbagai fakta ekonomi dan permasalahan begitu kompleks perlu direspon dengan berbagai kebijakan yang tepat. Dinamika yang terjadi 
pada sektor perekonomian Indonesia pada massa lalu menunjukkan ketidak berhasilan dalam pembangunan bidang ekonomi. Meskipun pembangunan ekonomi pada massa lampau berorientasi dan memfokuskan pada pembangunan nasional dan mengutamakan pertumbuhan ekonomi nasional, tetapi pilar-pilar pertumbuhan ekonomi masih sangat rapuh, dan pertumbuhan ekonomi yang terjadi tidak berkualitas karena dinilai belum mampu mengangkat kesejahteraan masyarakat.

Undang-undang No. 32 tahun 2004 tentang perubahan atas UU nomor 22 tahun 1999 tentang Otonomi Daerah, telah menyebabkan pergeseran dalam pembangunan ekonomi yang bermula bersifat sentralisasi, mengarah pada desentralisasi, yaitu dengan memberikan keleluasaan kepada daerah untuk membangun wilayahnya termasuk dalam bidang ekonominya. Hal ini menjadi angin baru bagi sistem pemerintahan di Indonesia yang memberikan warna baru bagi penyelenggaraan pemerintahan secara multidimensi. Dari prespektif geoekonomi, pembangunan regional di semua sektor ekonomi yang meliputi, pertanian, pertambangan dan penggalian, industri penggolahan, listrik, gas dan air, bangunan atau konstruksi, perdangangan, hotel dan restaurant, pengangkutan, dan komunikasi, jasa keuangan, persewaan, dan jasa perusahaan, jasajasa harus terus mengalami perbaikan.

Namun demikian perbaikan pembangunan regional di semua sektor ekonomi tersebut masih jauh dibanding potensinya. Di dalam kerangka ekonomi daerah, pembangunan ekonomi adalah suatu proses dimana pemerintah daerah dan masyarakatnya mengelola sumberdaya-sumberdaya yang ada dan membentuk suatu pola kemitraan antara pemerintah daerah dengan sektor swasta untuk menciptakan suatu lapangan kerja baru dan merangsang perkembangan ekonomi daerah. Menurut Arsyad, (1999:289) untuk pencapaian yang menjadi tujuan pembangunan ekonomi daerah tersebut dibutuhkan kebijakankebijakan pembnagunan yang didasarkan pada kekhasan daerah (endogenous developmen), dengan menggunakan potensi sumberdaya lokal. 


\begin{tabular}{|c|c|}
\hline Perbedaan kondisi daerah & jukkan bahwa \\
\hline bahwa & ndangtan \\
\hline embangunan vang seharusnva & kabupaten di Madura masih jauh dari \\
\hline literapkan di suatu daerah, sehingga & rata-rata pendapatan perkapita \\
\hline penekanan dalam perencanaan & kabupaten/kota di koridor utara Jawa \\
\hline pembangunan yang didasarkan harus & Timur yakni sebesar (Rp. 13.553.475) \\
\hline pada ciri khas dan karakteristik suatu & Pendapatan perkapita Kabupaten \\
\hline daerah. Untuk mencapai tujuan & Sumenep tahun 2006 (Rp.5.297.082), \\
\hline pembangunan daerah kebijakan yang & Kabupaten \\
\hline perlu dilakukan adalah mengusahakan & 4.261.894), Kabupaten Sampang (Rp. \\
\hline semaksimal mungkin agar prioritas & 3.899.965), \\
\hline pembangunan daerah sesuai dengan & Pamekasan (Rp. 3.094.709). Jika \\
\hline potensi yang dimiliki masing masing & dibandingkan dengan pendapatan \\
\hline daerah. & disebagian \\
\hline Pulau Madura merupakan salah & kota/kabupaten di Koridor Utara Jawa \\
\hline satu kepulauan di propinsi Jawa & Timur sangatlah rendah. Perbedaan \\
\hline Timur yang terdiri dari empat & nilai pendapatan perkapita tersebut \\
\hline kabupaten yaitu Bangkalan, Sampang & merupakan Indikator \\
\hline dan Sumenep yang saat ini & menunjukkan kesenjangan wilay \\
\hline tergolong tertinggal dibanding & hal tersebut juga menunjukkan tingkat \\
\hline wilayah sekita & kemakmuran di daerah pulau Madura \\
\hline & asih rendah. \\
\hline
\end{tabular}




\section{Gambar 1. Perbandingan Pendapatan Perkapita Kabupaten di Madura dengan Kabupaten di Daerah Jawa Timur Koridor Utara Tahun 2006}

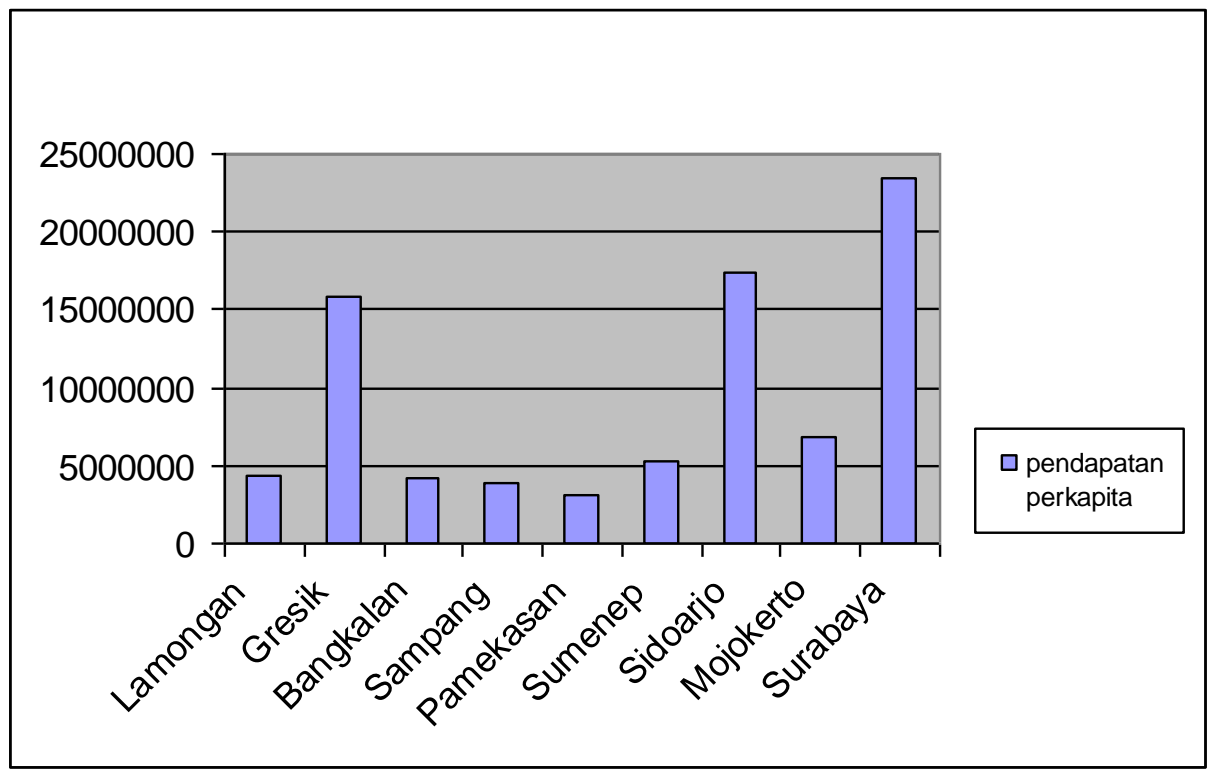

Sumber: BPS Jawa Timur (diolah)

Permasalahan - permasalahan di atas bila dikaji lebih jauh, ternyata meninggalkan masalah bom waktu yang justru dapat menghancurkan Pulau Madura yang terkenal dengan kerapan sapinya memiliki berbagai macam potensi ekonomi. perekonomian Jawa Timur dalam Madura merupakan salah satu jangka panjang jika diabaikan begitu penghasil utama garam dan tembakau saja. Hal ini sebenarnya lebih di Indonesia, di samping itu di pulau disebabkan pembangunan ekonomi Madura menyimpan potensi hasil selama ini lebih ditekankan pada pertambangan, meliputi bahan galian, pertumbuhan ekonomi saja dan belum serta energi yang cukup menjanjikan pada tataran pertumbuhan seperti Gas alam dan minyak bumi. pembangunan itu sendiri yang dapat menciptakan efisiensi dan pemerataan ekonomi. Jadi yang perlu ditekankan adalah pada masalah pemerataan pembangunan dan kualitas pembangunan itu sendiri. Namun demikian pengolahan serta pemanfaatan potensi-potensi yang ada ini belum dilakukan secara optimal sehingga tingkat pembangunan yang ada di Pulau Madura belum maksimal. Dampak yang terjadi dengan adanya kondisi tersebut yaitu 
kurangnya tingkat kesejahteraan dan adanya kesenjangan antar wilayah dan kabupaten yang terdapat di Pulau Madura.

Pulau Madura terdiri dari empat kabupaten mulai dari Bangkalan, Sampang, Pamekasan dan Sumenep dan terdiri dari pulau-pulau kecil yang jumlahnya mencapai 127 pulau. Berbagai upaya dilakukan oleh pemerintah Propinsi Jawa Timur untuk memaksimalkan berbagai potensi yang dimiliki oleh Pulau Madura, agar dapat memacu akselerasi pembangunan di wilayah Madura, dimana salah satunya yaitu dengan dibangunnya Jembatan Suramadu yang merupakan akses yang paling cepat untuk menghubungkan kota di Jawa Timur ke Pulau Madura. Tiga tahun beroprasinya Jembatan Suramadu diharapkan secara tidak langsung dapat mendorong terpacunya perekonomian, sehingga berdampak positif untuk mengembangkan potensi yang dimiliki Pulau Madura dan tidak lagi terpusat di wilayah Surabaya dan sekitarnya.

\section{METODE PENELITIAN}

Penelitian ini dilakukan di Pulau madura dengan menggunakan empat Kabupaten yang ada di Kepulauan Madura, yaitu Kabupaten Bangkalan, Sampang, Pamekasan dan Sumenep. Adapun alat-alat analisis yang digunakan untuk menganalisis data adalah Analisis Location Quotient (LQ), Analisis Tipologi Klassen, dan Analisis Gravitasi.

\section{PEMBAHASAN}

Analisis Tipologi Klassen di gunakan untuk mengetahui gambaran tentang pola pertumbuhan ekonomi pada daerah atau kabupaten. Tipologi klassen pada dasarnya membagi daerah berdasarkan dua indikator utama, yaitu pertumbuhan ekonommi daerah dan pendapatan perkapita daerah. Kriteria yang di gunakan untuk membagi daerah kabupaten / kota dalam penelitian ini sebagai berikut: Pertama, Daerah cepat maju dan cepat tumbuh (High growth and high income), adalah daerah yang memiliki tingkat pertumbuhan ekonomi dan pendapatan per kapita yang lebih tinggi dibandingkan ratarata kabupaten di Madura. 
Kedua, Daerah maju tapi berbeda antara yang satu dengan yang tertekan (high income but low lain. Dengan analisis tipologi Klassen growth), adalah daerah yang memiliki pendapatan perkapita lebih tinggi, tetapi tingkat pertumbuhan ekonominya lebih rendah dibandingkan rata-rata pulau Madura. Ketiga, Daerah berkembang cepat (high growth but low income) adalah daerah yang memiliki tingkat pertumbuhan ekonomi tinggi, tetapi tingkat pendapatan perkapita lebih rendah dibanding rata-rata Pulau Madura. Keempat, Daerah relatif tertinggal (low growth and low income).adalah daerah yang memiliki tingkat pertumbuhan ekonomi dan pendapatan perkapita yang lebih rendah di bandingkan rata-rata Pulau Madura.

Hasil penelitian menunjukkan bahwa PDRB perkapita dan pertumbuhan PDRB pada masingmasing kabupaten di Pulau Madura selama kurun waktu tahun 20052009, rata-rata diatas 4\% untuk seluruh kabupaten di Pulau Madura (lihat tabel 1).

Berdasarkan analisa Tipologi Klassen pada tabel 2, dapat dilihat pola pertumbuhan ekonomi pada empat kabupaten di pulau Madura pada empat kabupaten di pulau Madura dapat di klasifikasikan menjadi empat pola pertumbuhan ekonomi, pertama adalah "Daerah cepat maju dan cepat tumbuh" yang termasuk dalam klasifikasi ini yaitu kabupaten Bangkalan. Kemudian yang kedua adalah "Daerah maju tapi tertekan" yaitu Kabupaten Sumenep, jika dilihat dari jumlah total Produk Domestik Regional Bruto (PDRB) yang di hasilkan Kabupaten Sumenep tergolong tinggi, hanya saja tingkat pertumbuhannya lambat. Berikutnya yang ketiga adalah "Daerah berkembang cepat" yaitu kabupaten Pamekasan, Kabupaten Pamekasan memiliki tingkat pertumbuhan Produk Domestik Regional Bruto (PDRB) yang tinggi, akan tetapi nilai dari Produk Domestik Regional Bruto (PDRB) masih relatif kecil. Dan terakhir yang keempat adalah "Daerah relatif tertinggal" yang termasuk dalam klasifikasi ini yaitu Kabupaten Sampang.

Tahap analisis berikutnya yaitu Metode Location Quotient (LQ) yang merupakan salah satu tehnik pengukuran yang paling terkenal dari 
model basis ekonomi untuk Pada tabel 3, dapat kita lihat menentukan sektor unggulan atau non unggulan. Nilai LQ dapat dikatakan sebagai petunjuk untuk dijadikan dasar untuk menentukan sektor yang potensial untuk dikembangkan. Karena sektor tersebut tidak saja dapat memenuhi kebutuhan di dalam daerah, akan tetapi dapat juga memenuhi kebutuhan di daerah lain. Seperti diketahui bahwa sektor unggulan merupakan sektor-sektor yang mempunyai nilai LQ > 1 sedang sektor bukan unggulan adalah sektorsektor yang mempunyai nilai LQ $<1$. Hasil perhitungan LQ pada empat kabupaten di Pulau Madura tahun 2005 sampai tahun 2009 lengkap diuraikan dalam tabel 3 . bahwa pada empat kabupaten di Madura tidak ada satupun daerah yang memiliki sembilan sektor unggulan secara keseluruhan. Tiap daerah hanya memiliki beberapa sektor unggulan, kecuali Kabupaten Bangkalan yang paling dominan dengan memiliki tujuh sektor unggulan.

Sektor pertanian merupakan sektor unggulan di dua kabupaten yang ada di Pulau Madura sejak awal tahun sampai akhir tahun analisis. Pada gambar di atas menggambarkan bahwa hasil analisis LQ rata-rata pada sektor pertanian tahun 2005 - 2009, kabupaten yang mempunyai sektor unggulan pertanian adalah Kabupaten Sumenep, dan Kabupaten Pamekasan.

Tabel 1. Rata- rata PDRB Per Kapita \& Pertumbuhan PDRB di Pulau Madura Atas Dasar Harga Konstan Tahun 2005-2009

\begin{tabular}{clcc}
\hline NO & \multicolumn{1}{c}{ Kabupaten } & PDRB Per Kapita & Pertumbuhan PDRB \% \\
\hline 1 & Bangkalan & $3.267 .762,5$ & 4,66 \\
2 & Sampang & $2.730 .196,8$ & 4,46 \\
3 & Pamekasan & $2.260 .463,2$ & 4,79 \\
4 & Sumenep & $4.686 .794,3$ & 4,24 \\
& Rata-rata & $3.236 .304,2$ & 4,54 \\
\hline
\end{tabular}

Sumber : BPS pada empat kabupaten di pulau Madura (diolah)

Tabel 2. Pola Pertumbuhan Ekonomian Masing-Masing Daerah Pada Empat Kabupaten di Pulau Madura

\begin{tabular}{ccccc}
\hline NO & Kabupaten & Pertumbuhan & PDRB Per Kapita & Kriteria \\
\hline 1 & Bangkalan & Tinggi & Tinggi & Cepat Maju dan Tumbuh \\
\hline
\end{tabular}




\begin{tabular}{llccc}
\hline 2 & Sampang & Rendah & Rendah & Relatif Tertinggal \\
3 & Pamekasan & Tinggi & Rendah & Berkembang Cepat \\
4 & Sumenep & Rendah & Tinggi & Maju Tapi Tertekan
\end{tabular}

Sumber : BPS pada empat kabupaten di pulau Madura (diolah)

Tabel 3. Rata-Rata Nilai LQ Sektor/subsektor Empat Kabupaten di Pulau

Madura Tahun 2005 - 2009

\begin{tabular}{|c|c|c|c|c|}
\hline \multirow{2}{*}{ Sektor/subsektor } & \multicolumn{4}{|c|}{ Kabupaten } \\
\hline & Sumenep & Pamekasan & Sampang & Bangkalan \\
\hline I. Pertanian & 1.15 & 1.12 & 0.99 & 0.70 \\
\hline Tanaman bahan makanan & 0.96 & 1.21 & 1.13 & 1.15 \\
\hline Tanaman perkebunan & 1.81 & 0.95 & 0.44 & 0.21 \\
\hline Peternakan & 0.59 & 2.25 & 1.35 & 0.78 \\
\hline Kehutanan & 0.34 & $\sim$ & 2.21 & 1.68 \\
\hline Perikanan & 1.54 & 0.81 & 1.1 & 0.2 \\
\hline II. Pertambangan \& penggalian & 1.01 & 0.33 & 2.25 & 0.41 \\
\hline Pertambangan Migas & 2.5 & $\sim$ & 0 & 0.1 \\
\hline Pertambangan non migas & $\sim$ & $\sim$ & $\sim$ & $\sim$ \\
\hline Penggalian & 0.74 & 0.39 & 2.66 & 0.47 \\
\hline III. industri Pengolahan & 1.04 & 0.42 & 0.38 & 1.77 \\
\hline Makanan dan minuman dan tembakau & 1.57 & 0.37 & 0.11 & 1.68 \\
\hline Tekstil barang dari kulit dan alas kaki & 0.17 & 1.25 & 0.87 & 4.08 \\
\hline Barangkayu dan hasil hutan lainnya & 0.82 & 1.51 & 1.03 & 1.26 \\
\hline Kertas dan barang cetakan & 0.04 & 0.07 & 0.11 & 3.75 \\
\hline Pupuk, kimia, danbarang dari karet & 0.22 & $\sim$ & 0.37 & 3.3 \\
\hline Semen dan barang galian bukan logam & 0.8 & 0.64 & 2.25 & 0.53 \\
\hline Logam dasar besi dan baja & 1.7 & $\sim$ & $\sim$ & 1.3 \\
\hline Alat angkutan mesin dan peralatan & 1.81 & 0.55 & 0.57 & 0.35 \\
\hline Barang lainnya & 0.7 & 0.54 & 0.83 & 1.87 \\
\hline IV. Listrik, Gas \& Air Bersih & 0.17 & 1.98 & 1.45 & 1.34 \\
\hline Listrik & 0.1 & 2.01 & 1.52 & 1.38 \\
\hline Gas kota & $\sim$ & $\sim$ & $\sim$ & $\sim$ \\
\hline Air bersih & 0.74 & 1.86 & 0.84 & 1.01 \\
\hline V. Kontruksi & 0.55 & 1.27 & 0.84 & 1.65 \\
\hline VI. Perdagangan Hotel \& Restoran & 0.87 & 0.64 & 1.03 & 1.39 \\
\hline Perdagangan & 0.87 & 0.6 & 1.05 & 1.41 \\
\hline Hotel & 0.74 & 1.04 & 1.22 & 1.2 \\
\hline Restoan & 1.03 & 1.77 & 0.42 & 0.94 \\
\hline VII. Pengangkutan \& Komunikasi & 0.81 & 0.97 & 0.59 & 1.64 \\
\hline Angkutan & 0.61 & 0.86 & 0.59 & 2.02 \\
\hline Komunikasi & 1.06 & 1.51 & 0.73 & 0.81 \\
\hline VIII. Keuangan, Persewaan \& Jasa prshn & 0.94 & 1.3 & 0.8 & 1.07 \\
\hline Bank & 0.75 & 2.61 & 0.25 & 1.01 \\
\hline Lembaga keuangan bukan bank & 1.02 & 1 & 0.16 & 1.63 \\
\hline Sewa bangunan & 1.03 & 1.07 & 1.04 & 0.88 \\
\hline Jasa perusahaan & 0.44 & 0.68 & 0.75 & 2.26 \\
\hline
\end{tabular}




\begin{tabular}{lcccc}
\hline IX. jasa - jasa & 0.84 & 1.27 & 0.89 & 1.18 \\
Pemerintahan umum & 0.73 & 1.42 & 1.26 & 0.96 \\
Swasta & 1.02 & 1 & 0.23 & 1.57 \\
\hline Sumber: BPS empat kabupaten di pulau Madura (diolah) & & &
\end{tabular}

Pada gambar 1, di paparkan keempat kabupaten di dukung oleh beberapa subsektor unggulan, diantaranya sektor perikanan, peternakan, dan tanaman bahan makanan. Dalam sektor ini Kabupaten Sumenep didukung oleh subsektor perikanan dan tanaman perkebunan. Sedangkan Kabupaten Pamekasan unggul di subsektor peternakan dengan nilai rata-rata LQ 2.25 dan tanaman bahan makanan. Meskipun di Kabupaten Sampang sektor pertanian bukan merupakan sektor unggulan namun subsektor perikanan daerah ini unggul dengan nilai rata-rata LQ sebesar 1.10 dan unggul juga di subsektor kehutanan. Begitu pula dengan Kabupaten Bangkalan unggul di subsektor tanaman bahan makanan dan kehutanan.

Sektor pertanian masih merupakan sektor yang diunggulkan untuk wilayah Pulau Madura karena empat kabupaten yang ada, sektor pertanian merupakan sektor basis dan selama periode analisis sektor tersebut mempunyai kontribusi yang besar terhadap pembentukan PDRB. Dengan kata lain sektor pertanian mempunyai kemampuan terhadap peningkatan perekonomian di tiap kabupaten.

Sejalan dengan hal tersebut untuk kedepannya suatu kebijakan yang pro pertanian yang selalu diarahkan pada penerapan sistem agribisnis terpadu dengan memanfaatkan secara optimal sumberdaya pertanian. Dengan adanya kebijakan tersebut diharapkan bisa mengembangkan pertanian yang tangguh dengan meningkatkan pendapatan dan taraf hidup petani melalui peningkatan produktifitas tenaga kerja. 
Gambar 1. Peta LQ Sektor Pertanian Pada Empat Kabupaten di Pulau

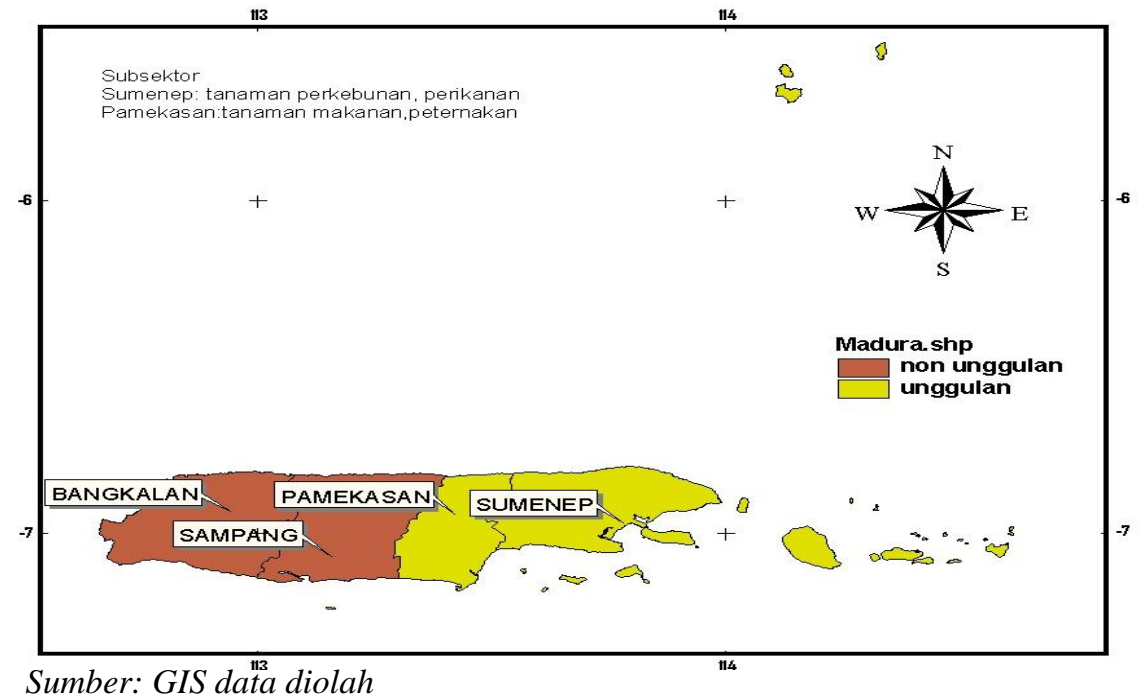

Gambar 2. Peta LQ Sektor Pertambangan dan Penggalian Pada Empat Kabupaten di Pulau Madura

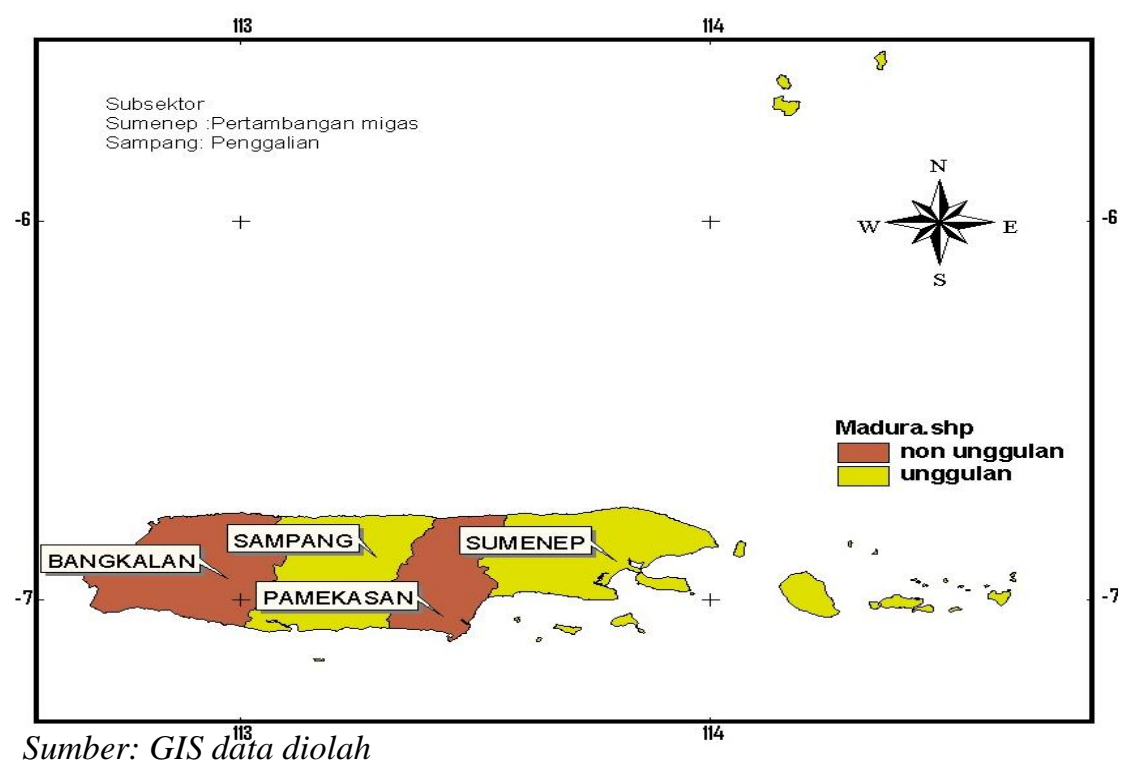




\section{Gambar 3. Peta LQ Sektor Industri Pengolahan Pada Empat Kabupaten di} Pulau Madura

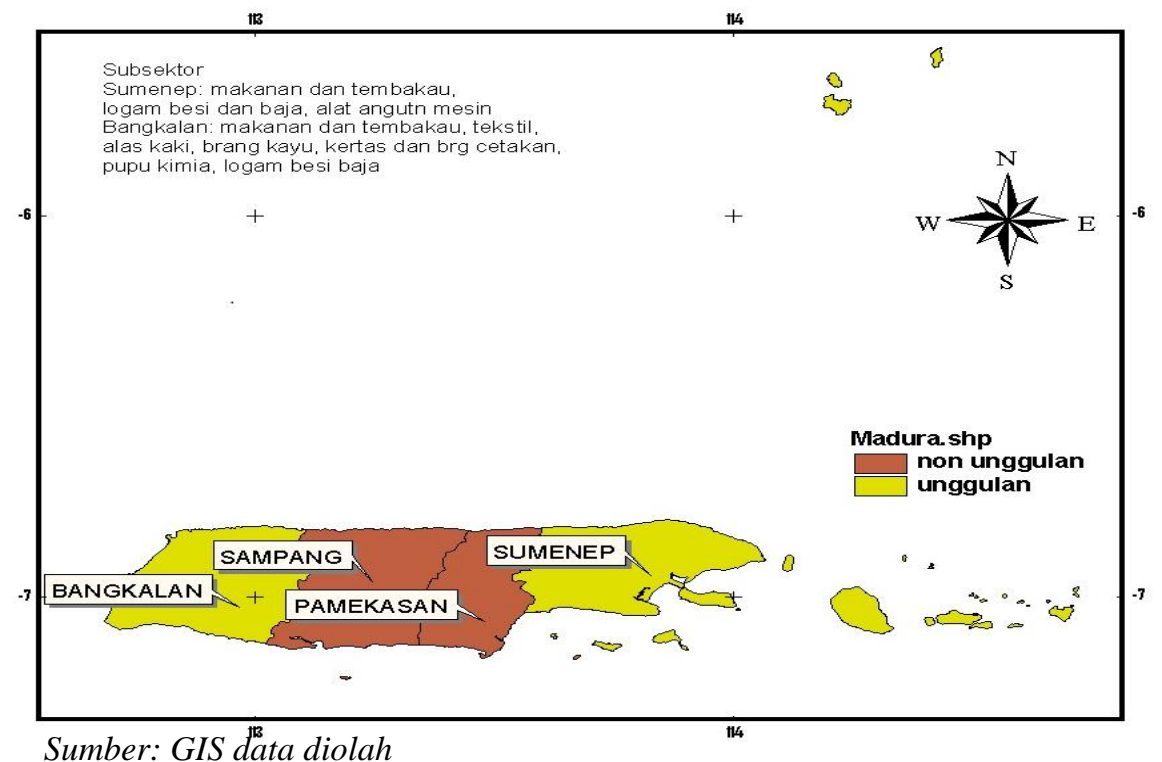

Hasil analisis LQ untuk sektor pertambangan dan penggalian hanya dua Kabupaten yang memiliki nilai LQ > 1 yakni Kabupaten Sumenep dan Kabupaten Sampang. Kabupaten Sampang yang menunjukkan sektor pertambangan dan penggalian sebagai sektor unggulan untuk daerahnya dengan nilai rata-rata LQ tertinggi sebesar 2.25, Kabupaten Sampang unggul di subsektor penggalian dengan nilai rata-rata LQ 2.66. Kabupaten Sumenep unggul di subsektor pertambangan migas dengan nilai LQ 2.50. Sedangkan dua kabupaten yang lain yakni Kabupaten Pamekasan dan Bangkalan masih mempunyai nilai LQ $<1$ untuk sektor ini, jadi sektor pertambangan dan penggalian masih belum bisa berkontribusi bagi kedua kabupaten ini.

Hasil analisis LQ pada sektor industri seperti terlihat dalam gambar 3 menunjukkan terdapat dua kabupaten yang memiliki sektor unggulan di sektor industri selama periode analisis, yaitu kabupaten Sumenep dan Kabupaten Bangkalan. Kabupaten Sumenep didukung oleh beberapa subsektor diantaranya makanan minuman dan tembakau. Sedangkan Kabupaten Bangkalan didukung oleh enam subsektor unggulan. Banyaknya subsektor unggulan di Kabupaten Bangkalan karena dipengaruhi letaknya yang 
dekat dengan Surabaya sebagai pusat perekonomian di Jawa Timur.

Bagi Kabupaten Sampang dan Pamekasan sektor industri pengolahan belum termasuk sektor unggulan karena nilai LQ $<1$. Minimnya sektor industri pengolahan disebabkan karena daerah di wilayah Madura menghasilkan bahan mentah yang langsung di jual tanpa adanya proses penambahan nilai barang. Selain itu masih minimnya investasi juga menjadi salah satu penyebab sektor industri pengolahan belum bisa menjadi sektor unggulan tiap kabupaten di Pulau Madura. Hasil analisis LQ pada sektor Litrik Gas dan Air Bersih selama periode analisis 2005-2009 menunjukkan ada tiga kabupaten dengan nilai LQ > 1 yaitu Kabupaten Bangkalan, Kabupaten Pamekasan, dan Kabupaten Sampang. berarti sektor listrik dan air bersih merupakan sektor unggulan pada tiga kabupaten di wilayah Pulau Madura. Nilai ratarata LQ tertinggi 1.98 pada sepanjang tahun analisis dimiliki oleh Kabupaten Pamekasan. Dari empat kabupaten yang ada di Pulau Madura hanya terdapat satu kabupaten yang memiliki sektor non unggulan pada sektor ini selama tahun analisis yaitu Kabupaten Sumenep. Dalam sektor ini, Listrik merupakan subsektor unggulan di tiga kabupaten yaitu Kabupaten Pamekasan, Sampang dan Bangkalan.

\section{Gambar 4. Peta LQ Sektor Listrik Gas dan Air Bersih Pada Empat}

\section{Kabupaten}

\section{di Pulau Madura}

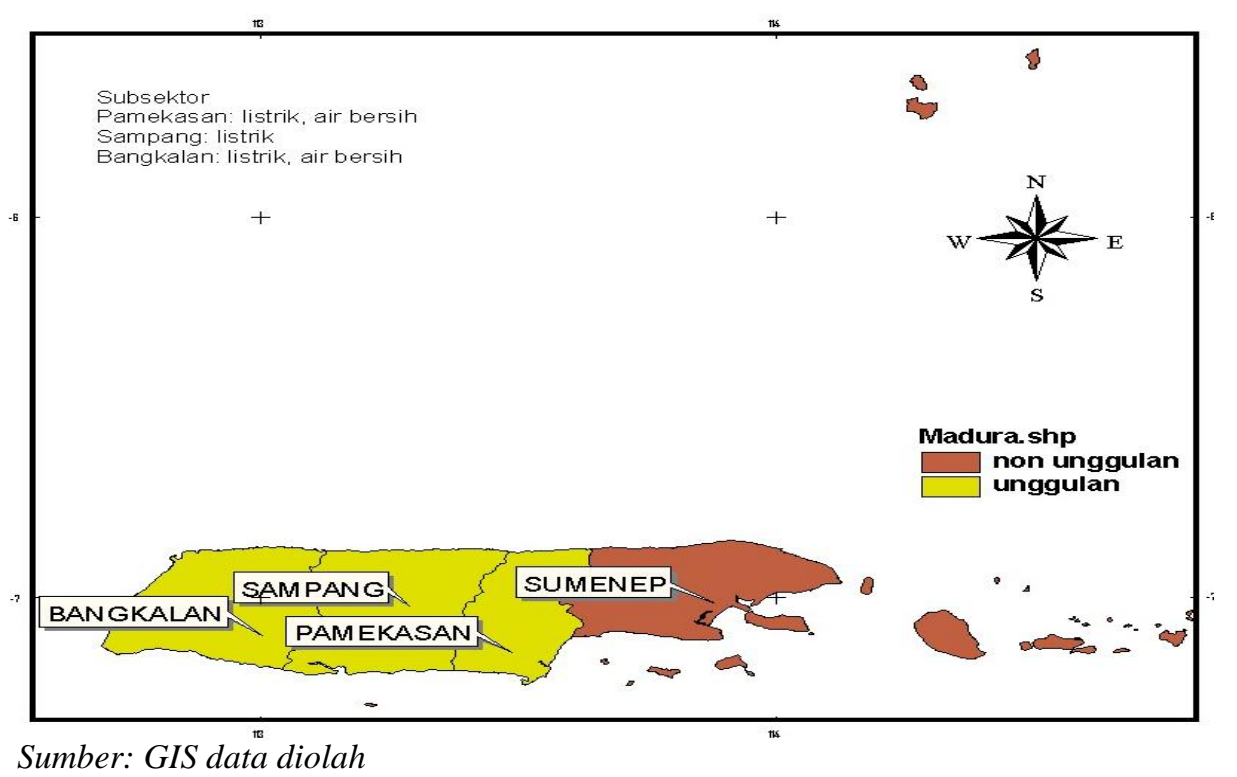




\section{Gambar 5. Peta LQ Sektor Bangunan Pada Empat Kabupaten di Pulau}

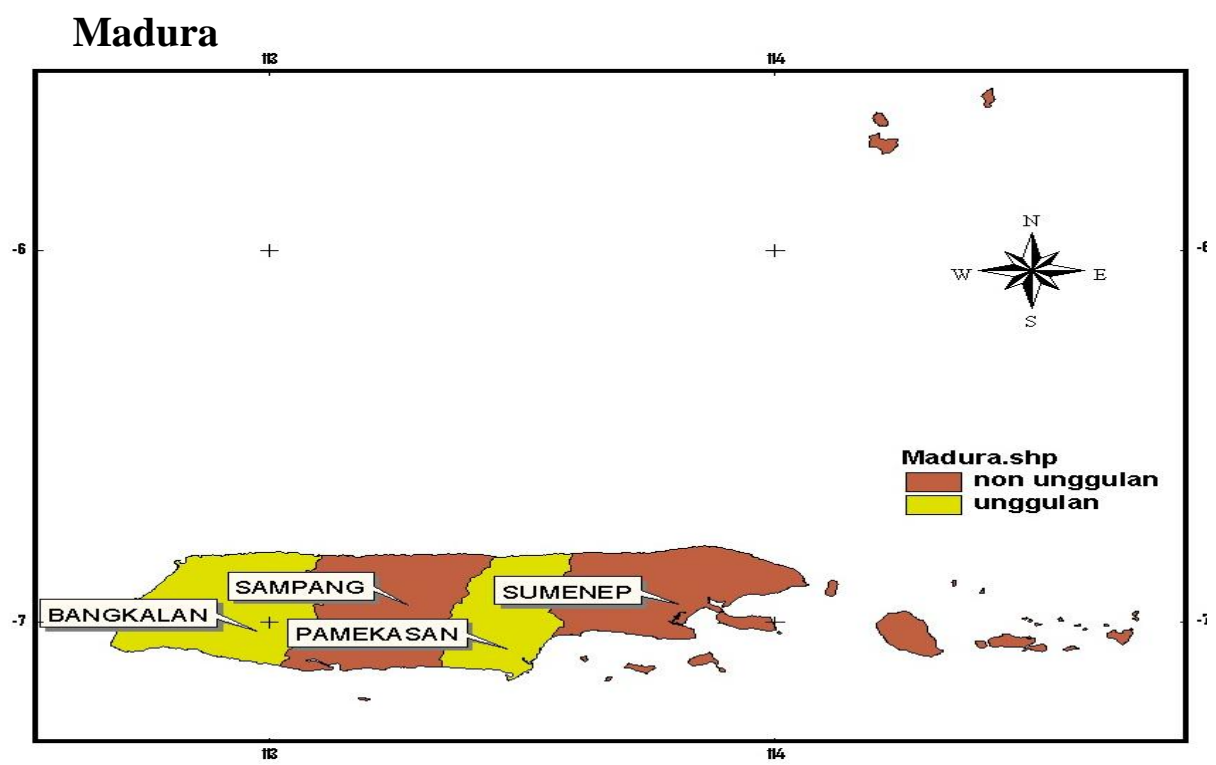

Sumber: GIS data diolah

\section{Gambar 6. Peta LQ Sektor Perdagangan, Hotel dan Restoran Pada Empat}

\section{Kabupaten di Pulau Madura}

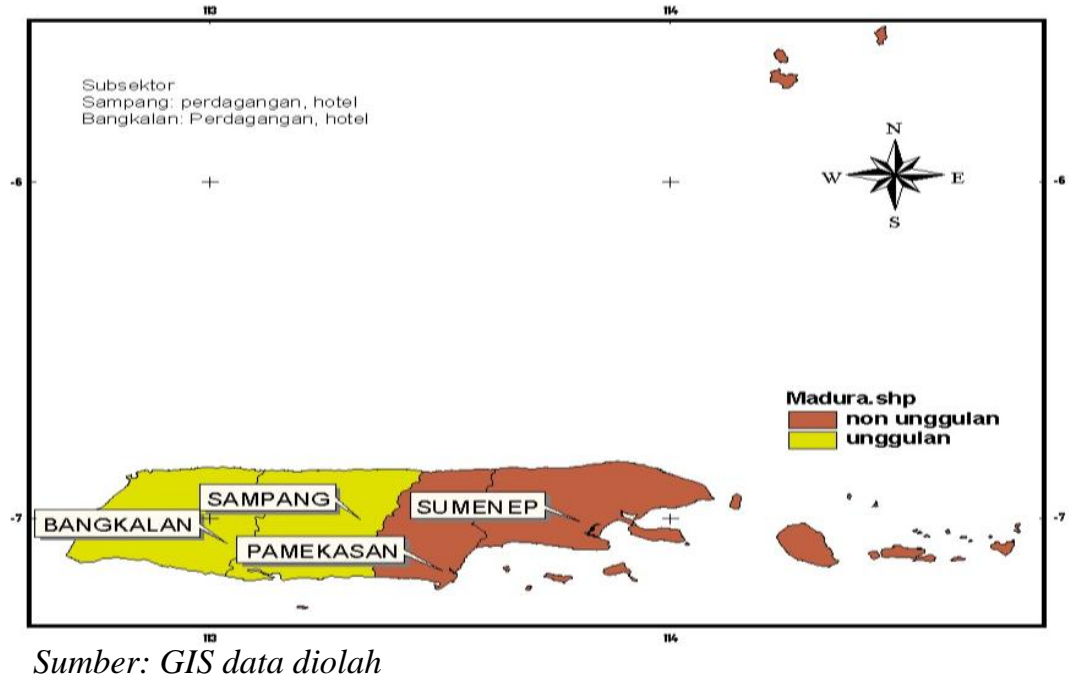

Berdasarkan gambar 5, untuk sektor bangunan hanya ada dua dua kabupaten yang ada di Pulau Madura suasana yang nyaman dan kondusif yang mempunyai sektor unggulan sehingga banyak orang yang mendirikan bangunan. Sedangkan Kabupaten Sumenep dan Kabupaten selama periode analisis yakni Sampang mempunyai nilai LQ $<1$ Kabupaten Pamekasan dan yang berarti sektor bangunan Bangkalan, hal ini karena di kedua merupakan non unggulan pada daerah kabupaten tersebut didukung oleh ini. 
Hasil analisis LQ untuk Komunikasi seperti terlihat dalam Perdagangan, Hotel dan Restoran gambar menunjukkan bahwa dari merupakan unggulan di dua empat Kabupaten yang ada di Pulau kabupaten di Pulau Madura yaitu Madura hanya terdapat satu daerah Kabupaten Sampang dan Kabupaten yang memiliki sektor unggulan di Bangkalan selama tahun analisis. sektor Pengangkutan dan Komunikasi Kedua kabupaten ini umumnya yakni Kabupaten Bangkalan yang memiliki unggulan di subsektor konsiten sejak periode analisis, hal ini perdagangan dan hotel. Kabupaten karena bangkalan didukung oleh Bangkalan memiliki nilai rata-rata LQ tertingi pada sektor ini dengan nilai 1.39, hal ini didukung dengan letak Kabupaten Bangkalan yang dekat dengan Kota Surabaya sebagai pusat perekonomian di Jawa Timur, sehingga memudahkan untuk aktifitas perdagangaan. Begitu pula subsektor hotel dan restoran masih belum bisa berkontribusi dengan baik karena masih minimnya industri pariwisata di Madura. Sektor ini masih belum menjadi non unggulan karena nilai LQ $<1$. adanya penyeberangan angkutan kapal Ferry dari Pelabuhan Kamal Bangkalan ke Dermaga Perak Surabaya yang merupakan satusatunya pintu masuk menuju Pulau Madura sebelum beroperasinya jembatan Suramadu, sehingga merupakan sumber pendapatan bagi daerah. Meskipun sektor ini bukan sektor unggulan di daerah Madura, namun Kabupaten Sumenep dan Kabupaten Pamekasan memiliki subsektor unggulan di bidang komunikasi.

Hasil analisis LQ pada sektor Sektor Pengangkutan dan 
Gambar 7. Peta LQ Sektor Pengangkutan dan Komunikasi Pada Empat Kabupaten di Pulau Madura

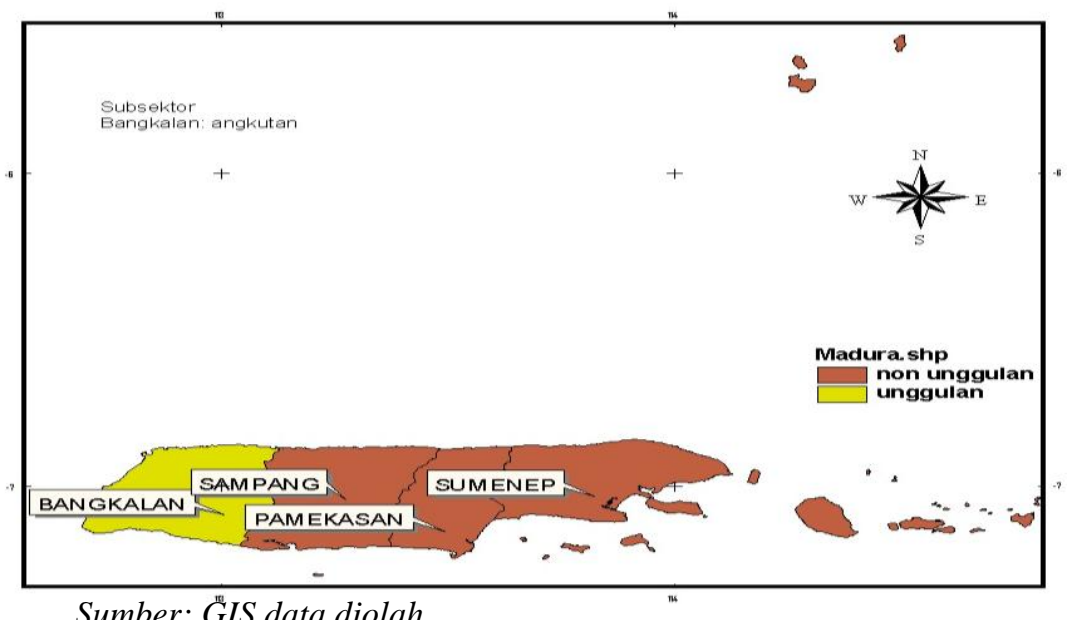

Gambar 8. Peta LQ Sektor Keuangan, Persewaan dan Jasa Perusahaan Pada Empat Kabupaten di Pulau Madura

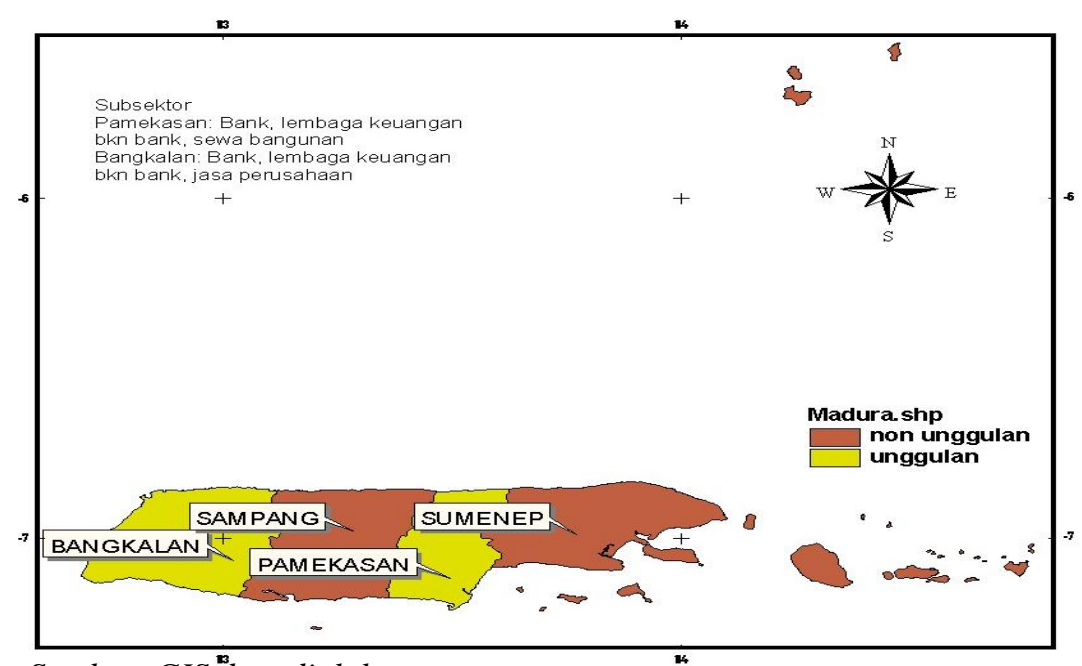

Sumber: GIS data diolah 


\section{Gambar 9. Peta LQ Sektor Jasa - Jasa Pada Empat Kabupaten di Pulau}

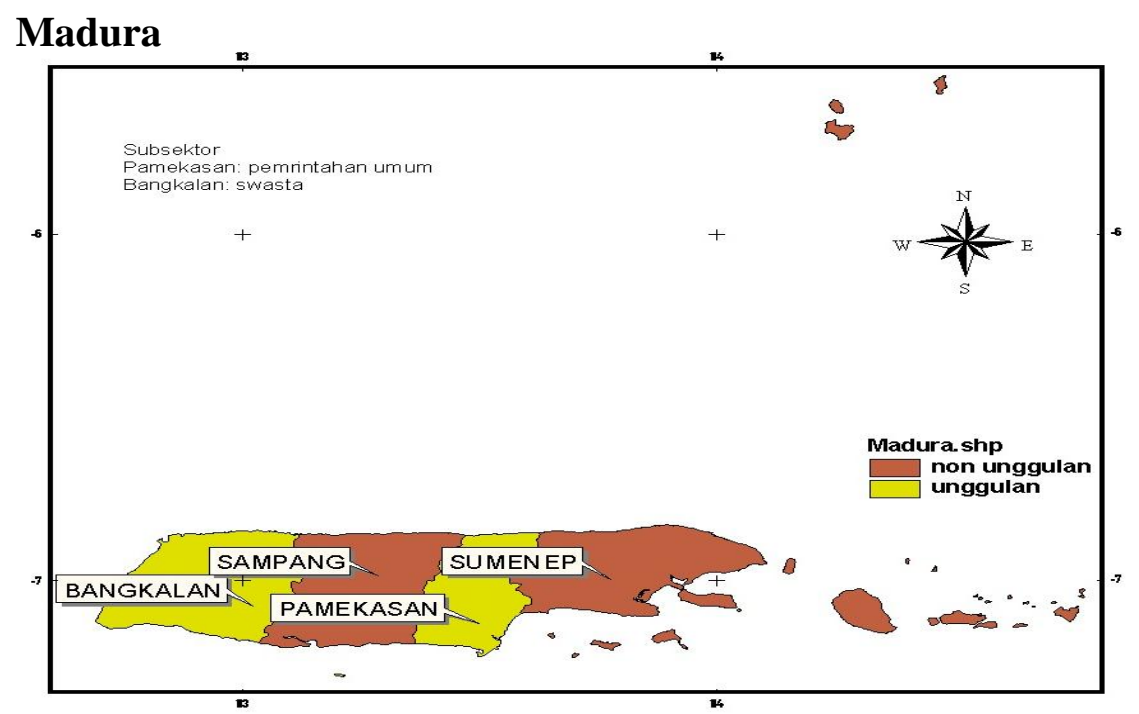

Sumber: GIS data diolah

Hasil analisis LQ untuk sektor keuangan, persewaan, jasa perusahaan untuk kabupaten terlihat bahwa hanya ada dua kabupaten yang mempunyai nilai LQ > I sepanjang tahun analisis yakni Kabupaten Pamekasan dengan LQ rata-rata sebesar 1.30 dan Kabupaten Bangkalan dengan nilai rata-rata LQ sebesar 1.07. Kabupaten lain yakni Kabupaten Sampang dan Sumenep pada sektor ini masih bukan unggulan di masing-masing wilayahnya karena mempunyai nilai LQ $<1$.

Hasil LQ subsektor Bank dan Lembaga Keuangan Bukan Bank juga merupakan subsektor unggulan di Kabupaten Bangkalan, Kabupaten Pamekasan dan Kabupaten Sumenep. Sedangkan subsektor sewa bangunan merupakan unggulan di tiga kabupaten yaitu, Kabupaten Sumenep, Pamekasan dan Bangkalan. Hasil analisis LQ pada sektor jasa-jasa seperti terlihat dalam gambar di atas menunjukkan bahwa hanya dua kabupaten di pulau Madura memiliki sektor unggulan di sektor jasa-jasa karena memiliki nilai LQ > 1 yaitu Kabupaten Pamekasan dan Kabupaten Bangkalan.. Untuk subsektor jasa-jasa pemerintahan masih merupakan subsektor unggulan pada Kabupaten Pamekasan dan Kabupaten Sampang. Sedangkan Kabupaten Bangkalan dan Kabupaten Sumenep memiliki subsektor unggulan dari swasta karena memiliki nilai $L Q>1$. 
Sembilan sektor yang dianalisis di empat kabupaten yang berada di Pulau Madura tidak ada satupun daerah yang mempunyai sektor unggulan secara keseluruhan pada tahun analisis. Kabupaten Bangkalan merupakan daerah yang paling banyak memiliki sektor unggulan yaitu sebanyak tujuh sektor dan kedua yaitu Kabupaten Pamekasan dengan lima sektor. Sedangkan kedua kabupaten yang masing- masing memiliki tiga sektor unggulan sepanjang tahun analisis adalah Kabupaten Sumenep dan Kabupaten Sampang.

Sektor Listrik Gas dan air bersih merupakan sektor paling dominan di Pulau Madura karena tiga kabupaten mempunyai sektor tersebut. Sedang Pertanian, Pertambangan Penggalian, Keuangan dan sektor Jasa-jasa merupakan sektor unggulan yang masing-masing dimiliki dua kabupaten di Pulau Madura. Sektor Pertambangan dan Penggalian merupakan unggulan bagi Kabupaten Sumenep dan Sampang. Berikutnya adalah sektor Bangunan merupakan sector unggulan yang dimiliki oleh dua kabupaten yakni Kabupaten Pamekasan dan
Bangkalan. Sedangkan Sektor Pengangkutan dan Telekomunikasi merupakan sektor unggulan yang hanya dimiliki oleh Kabupaten Bangkalan. Untuk subsektor unggulan kabupaten Bangkalan memiliki jumlah terbanyak dengan 18 subsektor unggulan, disusul kedua Kabupaten Pamekasan dengan 13 subsektor, kemudian Kabupaten Sampang dengan 12, dan yang terakhir adalah Kabupaten Sumenep dengan jumlah 11 subsektor unggulan. Secara rinci kompilasi analisis LQ untuk empat kabupaten di Pulau Madura yang mempunyai sektor unggulan sepanjang tahun analisis terlihat dalam tabel 4 .

Tahapan analisis berikutnya yaitu analisis gravitasi, analisis ini digunakan untuk mengetahui interaksi antar daerah, dimana suatu daerah dapat diketahui bagaimana suatu daerah dengan adanya interaksi antar wilayah maka suatu daerah akan saling melengkapi dan bekerjasama dengan daerah lain untuk meningkatkan laju pertumbuhan ekonomi masing-masing wilayah. Pertumbuhan ekonomi daerah tidak hanya dipengaruhi oleh faktor intern tetapi juga faktor ekstern yaitu hubungan interaksi dengan daerah lainnya. Prosesnya ditandai dengan 
adanya interaksi antar daerah yang berupa aktifitas ekonomi, aktifitas sosial dan komunikasi antar penduduk.

Tolok ukur dari metode ini adalah jarak antar daerah dengan jumlah penduduk dari masing masing daerah yang diteliti. Perhitungan besarnya interaksi antar kabupaten di Pulau Madura dengan daerah disekitarnya dengan Metode Gravitasi hasilnya dapat dilihat dalam tabel 5.

Berdasarkan tabel 5, dapat diketahui bahwa interaksi spatial terbesar adalah antara Kabupaten Sampang dengan Pamekasan kemudian Kabupaten Sumenep dengan Pamekasan, dan interaksi spatial terendah adalah antara kabupaten Sampang dengan Pamekasan, kemudian kabupaten Sumenep dengan kabupaten Pamekasan, kabupaten Sampang dengan kabupaten Bangkalan dan yang terendah yaitu kabupaten Bangkalan dengan kabupaten Sumenep. Berdasarkan pada tolak ukur metode Gravitasi besarnya interaksi spatial antara kabupaten Sampang dengan Kabupaten Pamekasan merupakan terbesar hal ini dikarenakan kedekatan jarak antara keduanya yaitu hanya $25 \mathrm{Km}$, kemudian besarnya interaksi ini meningkat sejalan bertambahnya jumlah penduduk dari masing-masing daerah.

\section{Tabel 4. Hasil Kompilasi Analisis LQ Pada Empat Kabupaten di Pulau}

\section{Madura}

Tahun 2005-2009

\begin{tabular}{llccccccccccc}
\hline & \multicolumn{1}{c}{ No } & Nama Kabupaten & & & \multicolumn{1}{c}{ Sektor } & & & & & Jumlah \\
& & 1 & 2 & 3 & 4 & 5 & 6 & 7 & 8 & 9 & $\begin{array}{c}\text { sektor } \\
\text { unggulan }\end{array}$ \\
\hline 1 & Sumenep & $\mathrm{U}$ & $\mathrm{U}$ & $\mathrm{U}$ & $\mathrm{NU}$ & $\mathrm{NU}$ & $\mathrm{NU}$ & $\mathrm{NU}$ & $\mathrm{NU}$ & $\mathrm{NU}$ & 3 \\
2 & Pamekasan & $\mathrm{U}$ & $\mathrm{NU}$ & $\mathrm{NU}$ & $\mathrm{U}$ & $\mathrm{U}$ & $\mathrm{NU}$ & $\mathrm{NU}$ & $\mathrm{U}$ & $\mathrm{U}$ & 5 \\
3 & Sampang & $\mathrm{NU}$ & $\mathrm{U}$ & $\mathrm{NU}$ & $\mathrm{U}$ & $\mathrm{NU}$ & $\mathrm{U}$ & $\mathrm{NU}$ & $\mathrm{NU}$ & $\mathrm{NU}$ & 3 \\
4 & Bangkalan & $\mathrm{NU}$ & $\mathrm{NU}$ & $\mathrm{U}$ & $\mathrm{U}$ & $\mathrm{U}$ & $\mathrm{U}$ & $\mathrm{U}$ & $\mathrm{U}$ & $\mathrm{U}$ & 7 \\
& Jumlah kabupaten & 2 & 2 & 2 & 3 & 2 & 0 & 1 & 1 & 2 & \\
\hline
\end{tabular}

Sumber : Hasil analisis LQ per sektor

Keterangan : 1. Pertanian . 2. Pertambangan dan Penggalian . 3. Industri Pengolahan .

4. Listrik, Gas dan Air Bersih . 5. Bangunan . 6. Perdagangan Hotel \& Restoran.

7.Pengangkutan \& Telkom. 8. Keuangan,Persewaan ,Jasa Perusahaan . 9. Jasa - jasa 
Tabel 5. Urutan Nilai Gravitasi Antar Kabupaten di Pulau Madura Tahun 2006-2009

\begin{tabular}{|c|c|c|c|c|c|}
\hline \multirow{2}{*}{ No } & \multirow{2}{*}{ Kabupaten } & \multicolumn{4}{|c|}{ Tahun } \\
\hline & & 2006 & 2007 & 2008 & 2009 \\
\hline 1 & $\begin{array}{l}\text { Sampang - } \\
\text { Pamekasan }\end{array}$ & 6.533 .118 .897 & 7.112.988.633 & 7.828.239.411 & 8.566 .906 .398 \\
\hline 2 & $\begin{array}{l}\text { Pamekasan - } \\
\text { Sumenep }\end{array}$ & 2.309.672.633. & 2.521 .143 .444 & 2.759 .432 .287 & 3.017 .825 .448 \\
\hline 3 & Bangkalan - Sampang & 1.706.578.392. & 1.870 .630 .618 & 2.047 .824 .980 & 2.228 .739 .910 \\
\hline 4 & Sampang - Sumenep & 1.493.636.120. & 1.630 .097 .814 & 1.776 .225 .955 & 1.927 .916 .274 \\
\hline 5 & $\begin{array}{l}\text { Bangkalan - } \\
\text { Pamekasan }\end{array}$ & 667.256 .893 & 731.531 .674 & 804.406 .501 & 882.117 .713 \\
\hline 6 & Bangkalan - Sumenep & 617.200 .891 & 678.272 .041 & 738.446 .292 & 803.156 .022 \\
\hline
\end{tabular}

Sumber: Berbagai Sumber diolah.

Pada tabel 5 dapat diketahui bahwa nilai terbesar adalah di Kabupaten Sampang dengan Kabupaten Pamekasan yaitu 8.566.906.398, kemudian antara Kabupaten Sumenep dengan Kabupaten Pamekasan dengan nilai 3.017.825.448, hubungan tersebut dipengaruhi dengan adanya hubungan perekonomian antar daerah tersebut khususnya perdagangan. Dengan adanya hubungan tersebut mengakibatkan aliran uang, dan aliran barang antar daerah melalui aktivitas perekonomian antar satu dengan yang lain. Hal ini menujukkan bahwa Kabupaten Pamekasan dapat dijadikan sebagai pusat pengembangan sekaligus pusat pertumbuhan bagi dua kabupaten sekaligus yaitu Kabupaten Sampang dan Kabupaten Sumenep, hal ini juga dilihat dari hasil analisis LQ Kabupaten Pamekasan memiliki jumlah sektor unggulan terbanyak ke dua setelah Kabupaten Bangkalan dengan lima sektor unggulan, disamping itu jarak antar kabupaten tersebut juga saling berdekatan. Dengan adanya interaksi antar wilayah maka suatu daerah akan saling melengkapi dan bekerjasama dengan daerah lain untuk meningkatkan laju pertumbuhan ekonomi masing-masing wilayah.

\section{PENUTUP}

Berdasarkan kriteria Tipologi Klassen dapat di ketahui bahwa pada empat kabupaten di pulau Madura termasuk pada klasifikasi daerah "cepat maju dan tumbuh" adalah kabupaten Bangkalan, untuk daerah 
yang termasuk klasifikasi "daerah maju tapi tertekan" adalah kabupaten Sumenep, untuk "daerah berkembang cepat" adalah kabupaten Pamekasan dan untuk "daerah relatif tertinggal " adalah kabupaten Sampang.

Sektor unggulan pada masingmasing pada empat kabupaten di pulau Madura adalah sebagai berikut: Kabupaten Sumenep memeliki sektor unggulang yakni Pertanian, Pertambangan dan Penggalian, Industri pegolahan, dan memiliki 11 subsektor unggulan. Kabupaten Pamekasan memiliki sektor unggulan Pertanian, Listrik, Bangunan, Keuangan, dan Jasa dan memiliki 13 subsektor unggulan. Sektor unggulan Kabupaten Sampang yaitu Pertambangan dan Penggalian, Listrik, Perdagangan, dan memiliki 12 subsektor unggulan. Sektor unggulan Kabupaten Bangkalan adalah Industri Pengolahan, Litrik, Bangunan, Perdagangan, Pengangkutan, Keuangan, Jasa-jasa dan memiliki 18 subsektor unggulan.

Analisis Gravitasi menunjukkan bahwa keterkaitan antar wilayah di pulau madura meliputi kabupaten Sampang dengan kabupaten Pamekasan, kemudian Kabupaten
Sumenep dengan Kabupaten Pamekasan, karena dari hasil analilisis masing daerah memiliki nilai tertinggi dengan nilai gravitasi sebesar 8.566.906.398 dan 3.017.825.448. Hal ini menunjukkan bahwa kabupaten Pamekasan dapat dijadikan sebagai pusat pertumbuhan dan pengembangan bagi kedua daerah baik Kabupaten Sampang maupun Kabupaten Sumenep.

Nilai urutan gravitasi selanjutnya adalah antara Kabupaten Bangkalan- Sampang, kemudian Kabupaten Sampang - Sumenep, berikutnya adalah Kabupaten Bangkalan - Sumenep, dan yang terahir yaitu antara Kabupaten Bangkalan - Sumenep.

\section{DAFTAR PUSTAKA}

Arsyad Lincolin, 2004. Ekonomi Pembangunan, Edisi Keempat, Yogyakarta: Penerbit : Sekolah Tinggi Ilmu Ekonomi YKPN

Arsyad Lincolin, 1999, Ekonomi Pembangunan, Edisi Ketiga, Yogyakarta. Penerbit: Sekolah Tinggi Ilmu Ekonomi YKPN:

Auliyaur Rahman, 2010, Analisa Potensi Ekonomi Sektoral Pada Empat Kabupaten di Pulau Madura, Skripsi Universitas Muhammadiyah 
Malang,

Tidak

Dipublikasikan.

Badan Pusat Statistik (BPS), Produk

Domestik Regional Bruto

Kabupaten/Kota se Jawa

Timur (2005-2009).

Hakim Abdul. 2004. Ekonomi Pembangunan, Yogyakarta: Ekoniska Kampus Fakultas Ekonomi Universitas Indonesia.

Kunarjo, 1997, Perencanaan dan Pembiayaan Pembangunan. Edisi ketiga Jakarta: UI Press.

Nadiatulhuda Mangun (2007). Analisis Potensi Ekonomi Kabupaten dan Kota di Provinsi Sulawesi Tengah. (Tesis S2, Program Pasca Sarjana Universitas Diponegoro Semarang., dipublikasikan).

RI UU No. 22 Tahun 1999 dan UU No. 32 2004, Tentang Otonomi Daerah.

Robinson Tarigan, 2004, Ekonomi Regional Teori dan Aplikasi, Bumi Aksara,

Jakarta.

Sjafrizal (1997), Pertumbuhan Ekonomi dan Ketimpangan
Regional Wilayah Indonesia Bagian Barat. Prisma. LP3ES No.3 Tahun XXVI. Jakarta.

Subandi, 2007, Sistem Ekonomi Indonesia. Edisi ketiga, Bandung: ALFABETA.

Sugiyanto. 2010, Penelitian Pengembangan Pusat-Pusat Pertumbuhan Ekonomi di Kabupaten Lamandau, Jurnal Mitra Ekonomi dan Manajemen Bisnis, Vol.1, No. 2, Oktober 2010, 202-215.

Sukirno, Sadono. 1985. Ekonomi Pembangunan. Jakarta: Bagian penerbit Fakultas Ekonomi Universitas Indonesia

Todaro, Maichel P, tahun 1999, Pembangunan Ekonomi Di Dunia ketiga, jilid 1, edisi keenam, Penerbit Erlangga, cetakan kedua.

Wiyadi dan Rina Trisnawati, 2002, Analisis Potensi Daerah Untuk Mengembangkan Wilayah Di Eks Karesidenan Surakarta Menggunakan Teori Pusat Pertumbuhan, Fokus Ekonomi, Desember 2002, download. 